\section{FRI0070 COST-EFFECTIVENESS OF BIOLOGIC AGENTS FOR RHEUMATOID ARTHRITIS WAS SUPERIOR TO TRADITIONAL/CONVENTIONAL DMARDS WHEN ANALYSED WITH NUMBER NEEDED TO TREAT(NNT) METHOD}

K. Harigane ${ }^{1}$, Y. Mochida ${ }^{1}$, K. Sahara ${ }^{1}$, N. Mitsugi ${ }^{2} .{ }^{1}$ Center For Rheumatic Diseases; ${ }^{2}$ Orthopaedic Surgery, Yokohama City University Medical Center, Yokohama, Japan

Background: Recently biologic agents are widely used for patients with rheumatoid arthritis (RA). Biologic agents are reported to have higher effectiveness than other disease-modifying anti-rheumatic drugs (DMARDs) including methotrexate (MTX), however, those new agents are more expensive.

Objectives: This study evaluated the cost-effectiveness of biologic agents for RA using number needed to treat (NNT) method. NNT is an index for determining the number of patients who need to be treated in order to reach a patient toward to clinical goal when a new treatment is introduced.

Methods: Fifty-three patients with RA was included in this study. These patients were introduced biologic agents between September 2012 to , March 2017 and continued same agent up to 24 weeks. NNT was calculated based on disease activity score (DAS28-ESR) and clinical disease activity index (CDAl) at 24 weeks. Ninety-four patients were investigated as a control group who treated with DMARDs. In addition, actual healthcare cost including doctor's fee, laboratory examination, prescription fee, and cost of biologic agents in each patient were calculated based on hospital's medical receipt, then averaged and compared between two groups.

Results: In biologic group, tocilizumab (TCZ) were used for 20 patients, golimmab (GLM) for 14 patients, etanercept (ETN) for 13 patients, and other biologics for six patients. In control group, 66 patients administered MTX and/or conventional DMARDs (csDMARDs), and 28 patients administered only csDMARDs. In biologic group, 53 patients $(79.2 \%)$ achieved remission in DAS28-ESR, and 24 patients $(45.2 \%)$ achieved remission in CDAI. On the other hand, the rate of remission was $61.7 \%$ and $23.4 \%$ respectively in control group. NNT was 1.26 (DAS28) and 2.21 (CDAI) in biologic group, and 1.62 and 4.27 respectively in control group. In biologic group, NNT based on DAS28-ESR of each agent was 1.11 of TCZ, 1.30 of ETN, 1.40 of GLM, and 1.50 of others (table 1). The total actual healthcare cost in the study period was 7,812.5 Euro (1044066 JPY; 1 Euro=133.6 JPY, in December 2017) in biologic group and 583.8 Euro (78020 JPY) in control group.

\begin{tabular}{llccccc} 
& & Number & Ave. & Remissio & ARR & NNT \\
\hline Diologic group & & 53 & 1.92 & 42 & 0.79 & 1.26 \\
& TCZ & 20 & 1.58 & 18 & 0.90 & 1.11 \\
& GLM & 14 & 2.10 & 10 & 0.71 & 1.40 \\
& ETN & 13 & 2.05 & 10 & 0.77 & 1.30 \\
& others & 6 & 2.56 & 4 & 0.67 & 1.50 \\
Control group & & 97 & 2.39 & 58 & 0.62 & 1.62 \\
& MTX & 66 & 2.30 & 41 & 0.61 & 1.61 \\
& csDMARDs & 28 & 2.63 & 17 & 0.61 & 1.65 \\
& & & & & & \\
& & Number & Ave. CDAl & Remissio & ARR & NNT \\
\hline Biologic group & & 53 & 4.31 & 24 & 0.45 & 2.21 \\
& TCZ & 20 & 2.94 & 11 & 0.55 & 1.82 \\
& GLM & 14 & 5.10 & 5 & 0.36 & 2.80 \\
& ETN & 13 & 4.52 & 7 & 0.54 & 1.86 \\
& others & 6 & 6.58 & 1 & 0.17 & 6.00 \\
Control group & & 94 & 5.43 & 22 & 0.23 & 4.27 \\
& MTX & 66 & 5.19 & 16 & 0.24 & 4.13 \\
& csDMARDs & 28 & 6.00 & 6 & 0.21 & 4.67
\end{tabular}

Conclusions: The total actual health care cost of biologic group was much higher than DMARDs group, however, the cost-effectiveness of biologics was superior to DMARDs from the stand point of NNT.

\section{REFERENCE:}

[1] Alberto B, et al. Efficacy and Treatment Costs of Monotherapy with bDMARDs in the Treatment of Rheumatoid Arthritis in Patients Intolerant to or Inappropriate to Continue Treatment with Methotrexate. Adv Ther 2016;33:1360-73.

Disclosure of Interest: K. Harigane: None declared, Y. Mochida: None declared, K. Sahara Grant/research support from: Takeda Pharmaceutical Company Limited, Daiichi Sankyo Company, Limited, Mitsubishi Tanabe Pharma Corporation, Teijin Limited Chugai Pharmaceutical Co., Ltd, Astellas Pharma Inc., N. Mitsugi: None declared

DOI: 10.1136/annrheumdis-2018-eular.2362

\section{FRI0071 \\ OUTCOMES FROM RHEUMATOLOGY AND} REPRODUCTIVE HEALTH CLINIC 2013-2016

K. Murray ${ }^{1}$, L. Moore ${ }^{2}$, C. O'Brien ${ }^{3}$, A. Clohessy ${ }^{3}$, C. Brophy ${ }^{3}$, P. Minnock ${ }^{2}$, A. B. Mongey ${ }^{1,2}$, E. Molloy ${ }^{1,2}$, O. FitzGerald ${ }^{1,2}$, S. Higgins ${ }^{3}$, M. Higgins ${ }^{3}$, F. McAuliffe ${ }^{3,4}$, D.J. Veale ${ }^{1,2},{ }^{1}$ Saint Vincent's University Hospital, Dublin 4; ${ }^{2}$ Our Lady's Hospice, Dublin 6; ${ }^{3}$ National Maternity Hospital, Dublin 2; ${ }^{4}$ UCD Perinatal Research Centre, School of Medicine, University College Dublin, Dublin, Ireland

Background: A multidisciplinary approach to pregnancy in women with rheu matic diseases will ensure best outcomes for mother and baby. ${ }^{1}$

Objectives: In 2013, we developed a dedicated nurse-led multidisciplinary Rheumatology Reproductive Health Clinic (RRHC) in order to provide a multidisciplinary service.

Methods: 98 women attended the RRHC from January 2013-16. They were prospectively assessed for age, diagnosis, medications, use of assisted reproductive technology (ART) and pregnancy outcomes.

Results: The mean (range) age was 35 years. ${ }^{19-48}$ The majority of patients had rheumatoid or psoriatic arthritis. The characteristics of the patients is summarised in table 1 and their outcomes in table 2. 24 women were on a biologic DMARD therapy at the time of conception. 10 discontinued in the first semester and 5 in the second trimester. 9 continued throughout their pregnancies. $90 \%$ of women surveyed were "very satisfied" with the physical and emotional support received in the clinic.

Abstract FRI0071 - Table 1. Patient Characteristics

\begin{tabular}{|c|c|}
\hline Diagnosis & Number of Patients \\
\hline Racumatord Arthrtis & 41 \\
\hline Psorlatic Arthrtus & 16 \\
\hline Ankylosing spondyntus & 8 \\
\hline Systemic Lupus Erythematosus & $T$ \\
\hline Juvenile Id Iopathe Arthnths & 5 \\
\hline Caronic Regional Pain Syndrome & 3 \\
\hline Granulomakosis with Polyangltis & 3 \\
\hline Rcactive Arthritis & 2 \\
\hline Behçet's Discase & 2 \\
\hline Siccas Syndrome & 2 \\
\hline Takayasu's Arteritis & 2 \\
\hline Raynaud's Syndrome & 2 \\
\hline Fioromyalgia syndrome & 2 \\
\hline Sarcoldosis & $T$ \\
\hline MIxed Connective TIssue DIsease & $T$ \\
\hline Systemic selerosis & $T$ \\
\hline Total & \\
\hline
\end{tabular}

Abstract FRI0071 - Table 2. Outcomes

\begin{tabular}{|c|c|}
\hline Outcome & Number of Patients \\
\hline Tnformation gathering only & TO \\
\hline $\begin{array}{l}\text { Pregnancy achieved } \\
\text { Using Assisted Reproductive } \\
\text { Technology }\end{array}$ & 62 \\
\hline Actively trying to achicve & 26 \\
\hline Total number of pregnancies & 88 \\
\hline Burths & 76 \\
\hline Mothers who had one olrth only & 49 \\
\hline $\begin{array}{l}\text { Mothers who had two births } \\
\text { (including one set of twins) }\end{array}$ & 27 \\
\hline Tst trimester pregnancy loss & $T T$ \\
\hline 2nd trimester pregnancy loss & $T$ \\
\hline $\begin{array}{l}\text { Nennatal death (renal aplasia } \\
\text { diagnosed in utero) }\end{array}$ & $T$ \\
\hline $\begin{array}{l}\text { Breastiecong conthued to } 6 \\
\text { week postpartum review }\end{array}$ & 21 \\
\hline Total number of women & 98 \\
\hline
\end{tabular}

Conclusions: This is the first report of results from a multidisciplinary RRHC These data show high levels of successful pregnancy outcomes and patient satisfaction.

The majority of patients had an inflammatory arthritis. Successful pregnancy outcomes were achieved in $70 \%$ of women actively trying to conceive. $38 \%$ of 